\title{
PROLOG: PENGEMBANGAN POTENSI TOLERANSI DAN PERSATUAN BANGSA MELALUI PENDIDIKAN AGAMA BERWAWASAN MULTIKULTURAL
}

\author{
Oleh \\ A.M Wibowo
}

\section{Multikultural di Indonesia}

Pendidikan secara ideal merupakan usaha untuk memproses seseorang memiliki kompetensi dalam bidang tertentu dan sekaligus sebagai proses humanisasi. Humanisasi adalah upaya memanusiakan manusia atau memproses manusia agar bermartabat dan berbudi mulia, religius dan berjiwa toleran tanpa membedakan suku, budaya, bahasa, agama, ekonomi gender dan lain sebagainya.

Pada konteks ke Indonesiaan upaya humanisasi menjadi sangat penting mengingat Indonesia merupakan negara kesatuan yang berbentuk kepulauan dan didiami lebih 200 juta penduduk yang terdiri dari 300 suku besar dan kecil, berbagai bahasa, budaya, agama serta berbagai aliran kepercayaan yang dianut oleh warga negara. Negara sebagaimana tercantum dalam UUD 1945 berkewajiban menjamin hakhak warga negaranya untuk bebas menjalankan agama dan kepercayaannya, berekspresi, memperoleh pendidikan, berpolitik, serta mengembangkan kebudayaannya. 
Provinsi Bali sebagai salah satu daerah di Indonesia memiliki keunikan dan keunggulan kebudayaan yang menarik pendatang untuk menetap dan mencari pekerjaan di provinsi ini. Sebagai konsekuensi daerah tujuan wisata; wisatawan manca negara dan domestik, maka mobilitas penduduk (migrasi) akan selalu terjadi di Bali. Fakta yang ada menunjukan jumlah "kaum pendatang", khususnya etnis Nusantara cukup besar di Bali.

Menurut data dari Badan Informasi dan Telematika Provinsi Daerah Bali tahun 2004 ada 22 jumlah paguyuban etnis Nusantara, seperti; Ikatan keluarga Batak (Sumatra Utara), Ikatan Keluarga Minang Saiyo Minang Kabau (Sumatra Barat), Paguyuban Mangle (Jawa Barat), Paguyuban Banyumasan (Jawa Tengah), Ikatan Keluarga Surakarta Hadiningrat (Jawa Tengah), Paguyuban Kesuma/Eks Karesidena Surakarta (Jawa Tengah), Paguyuban Ngeksigondo (Jogjakarta), Ikatan Keluarga Besar Flambomora (NTT), Ikatan Mahasiswa dan Masyarakat Papua (IMMAPA), Ikatan Keluarga Maluku Bali "IKEMAL", RKSS Kodya Denpasar Makasar Bugis, Ikatan Keluarga Toraja (IKAT), Ikatan Keluarga Sangihe Talaud (IKSAT), Ikatan Keluarga Maesa (Minahasa), Paguyuban Sosial Masyarakat Tionghoa (PSMTI), Ikatan Keluarga Ombay Alor (NTT), Paguyuban Klong-Bring Alor (NTT), Persaudaraan Warga Tegal (Jawa Tengah), Ketua Forum KKB, Kerukunan Keluarga Madura, Paguyuban Keluarga Sidoarjo (Jawa Tmur), dan Lembaga Adat Kebudayaan Aceh (Laka) (Geriya, 2004).

Banyaknya suku bangsa yang saat ini mendiami provinsi Bali jika tidak dikelola dengan baik maka akan menimbulkan potensi konflik yang besar baik atas nama agama, budaya, maupun ekonomi. Melihat kenyataan pluralitas dan kemajemukan provinsi Bali secara khusus dan Indonesia secara umum tersebut, menjadi tantangan tersendiri bagi pemerintah dan negara Indonesia untuk mengelola pluralitas dan kemajemukan tersebut. Alih-alih pluralitas dan kemajemukan tersebut menjadikan potensi integratif justru multikulturalisme dan pluralitas bangsa memungkinkan menjadi potensi disintegratif jika tidak dikelola dengan baik. 
Secara harfiah kata muktikutualisme sendiri berasal dari kata multikultural dengan penambahan sufiks isme. Multukultural mengacu pada suatu masyarakat yang terdiri dari beberapa kebudayaan (Sunarto,dkk,2004:1). Imbuhan isme tersebut memiliki makna suatu doktrin normatif atau sebuah ideologi yang dipahami oleh anggota masyarakat dan menjadi cara berpikir mereka dalam kehidupan seharihari.

Azra (2007) mengatakan bahwa masyarakat multikultural adalah suatu masyarakat yang terdiri dari beberapa macam kumunitas budaya dengan segala kelebihannya, dengan sedikit perbedaan konsepsi mengenai dunia, suatu sistem arti, nilai, bentuk organisasi sosial, sejarah, adat serta kebiasaan.

Multikultural juga dapat diartikan sebagai keragaman atau perbedaan terhadap suatu kebudayaan dengan kebudayaan yang lain. Sehingga masyarakat multikultural merupakan sekelompok manusia yang tinggal dan hidup menetap di suatu tempat yang memiliki kebudayaan dan ciri khas tersendiri yang mampu membedakan antara satu masyarakat dengan masyarakat yang lain.

Masyarakat Indonesia merupakan masyarakat dengan tingkat keanekaragaman yang sangat kompleks. Masyarakat dengan berbagai keanekaragaman tersebut dikenal dengan istilah mayarakat multikultural.

Kebudayaan adalah sesuatu yang menempel dalam kehidupan manusia. Kebudayaan lahir dari interaksi manusia dengan lingkungannya. Oleh karena itu budaya dan kebudayaan adalah sesuatu yang khas pada setiap komunitas. Kebudayaan bersifat memenuhi kebutuhan komunitas itu sendiri (self-sufficient). Kebudayaan adalah cara sebuah masyarakat mengatasi persoalannya sendiri. Suatu masyarakat dengan berbagai macam budaya membutuhkan suatu pemikiran untuk mempersatukannya untuk menjadi suatu bangsa yang utuh dan besar. Kegagalan pemilihan proses penyatuan suatu bangsa menyebabkan kegagalan menjadi bangsa dan rusaknya atau hilangnya suatu budaya. 
Agama adalah sesuatu yang sangat sakral, sehingga hampir tidak ada seorangpun yang tidak emosional ketika berbicara masalah agama, apalagi agama yang dianutnya menjadi trending topic dalam berbagai media karena ada sebagian kecil umatnya yang tidak seirama dengan kebanyakan. Agama juga menjadi sangat dibutuhkan ketika manusia berada dalam kehampaan spiritual dan pada saat yang sama mengalami kebuntuan dalam berbagai persoalan hidup dan kehidupan. Di sinilah agama menjadi sangat penting keberadaannya sehingga tidak akan hilang dari kehidupan manusia yang sebenarnya, meskipun ada sebagian kecil yang menjadikan agama sebagai simbol agar dapat diterima di masyarakat. Agama adalah realitas sosial yang di dalamnya tidak hanya terkandung ajaran yang bersifat normative doctrinal melainkan juga terdapat variabel pemeluk, tafsir ajaran, lembaga keagamaan, tempat suci serta bangunan ideologi yang dibangun dan dibela oleh para pemeluknya.

Salah satu peran agama dalam kehidupan bermasyarakat, berbangsa dan bernegara adalah mendinamisir masyarakat untuk menjaga keutuhan dan kerukunan bangsa, karena tidak ada satu agamapun yang mengajarkan untuk saling memusuhi atau saling berperang. Oleh karena itu, menjaga kehidupan manusia agar menjadi tertib dan teratur menjadi sebuah keniscayaan. Dengan demikian menurut Komarudin Hidayat, bahwa apabila terjadi konflik antaragama maka terdapat berbagai variabel yang terlibat, yang satu memperkuat yang lain, meskipun ada juga aspek ajaran yang menjadi kekuatan pencegah (Hidayat, 2000).

Dilihat dari jumlah varian agama, meskipun pemerintah Indonesia saat ini secara administratif hanya melayani (mengakui) enam agama terbesar di Indonesia (Islam, Kristen, Katholik, Hindu Budha, dan Khong $\mathrm{Hu} \mathrm{Cu}$ ), namun sebenarnya ada banyak varian agama yang tumbuh subur di Indonesia seperti Kaharingan, Sunda Wiwitan, Subud, Pangestu dan lain sebagainya.

Pada masa kini masyarakat suatu negara, yang majemuk dari segi etnis, budaya, agama memiliki gagasan untuk mengembangkan semangat kebangsaan yang sama. Gagasan itu dirumuskan dalam 
konsep masyarakat majemuk, dimana suatu pola hubungan yang mengakui adanya persamaan ras, suku dan antar golongan serta sudah mengenal pengakuan persamaan hak di bidang politik, perdata, ekonomi dan lain-lain. Dalam masyarakat majemuk terdapat berbagai perbedaan sosial, budaya dan politik yang dikukuhkan sebagai hukum ataupun sebagai konvensi sosial yang membedakan antara golongan mayoritas menjadi lawan dari yang minoritas.

Konflik Sosial berlatar belakang perbedaan budaya menjadi masalah penting dalam masyarakat Indonesia. Perbedaan budaya itu didasarkan sering bersumber dari asal-usul ras, etnisitas, agama, latar belakang sosial ekonomi, kelas sosial, pemahaman tentang gender dan semacamnya. Konflik-konflik tersebut sering terjadi dalam perjalanan sejarah bangsa Indonesia sejak Indonesia merdeka dan terus berlangsung hingga masa kini.

Secara historis-sosiologis, konflik sosial dapat dibedakan menjadi dua, yaitu konflik yang bersifat vertikal dan horisontal. Pada awal revolusi kemerdekaan, konflik tipe pertama lebih dominan dibandingkan dengan tipe ke dua. Sementara itu pada masa kini, konflik horizontal berlangsung seiring dengan konflik-konflik vertical (Wasino, 2012:1)

Proses perpindahan penduduk beserta kebudayaan asli yang dibawa pada daerah yang berbeda inilah yang terkadang membuat komintas manusia pada suatu daerah menjadi plural dan mudah menimbulkan konflik sosial. Masyarakat majemuk (plural society) menurut Furnifall memiliki potensi konflik yang cukup tinggi jika tidak dikelola dengan baik. Pierre L. van den Berghe sebagaimana dikutip Nasikun (1985, 67-68) menyatakan pada masyarakat majemuk sering segmentasi ke dalam bentuk kelompok-kelompok yang seringkali memiliki subkebudayaan yang berbeda-beda satu sama lain, memiliki struktur sosial yang terbagi-bagi ke dalam lembaga-lembaga yang bersifat nonkomplementer, kurang mengembangkan konsensus di antara para anggotanya terhadap nilai-nilai yang bersifat dasar, secara relatif seringkali mengalami konflik-konflik di antara kelompok yang satu 
dengan kelompok yang lain, secara relative integrasi sosial tumbuh di atas paksaan (coercion) dan saling ketergantungan di dalam bidang ekonomi; serta adanya dominasi politik oleh suatu kelompok atas kelompok-kelompok yang lain (Nasikun 1985).

Dari sekian banyak hal yang dianggap pemicu konflik pada masyarakat majemuk di Indonesia adalah masalah kebudayaan antar suku, agama dan ekonomi. Perbedaan kebudayaan atau agama memang potensial untuk mendestabilkan negara-bangsa. Karena memang terdapat perbedaan dalam orientasi dan cara memandang kehidupan ini, sistem nilai yang tidak sama, dan agama yang dianut masing-masing juga berlainan. Perbedaan di dalam dirinya melekat (inherent) potensi pertentangan, suatu konflik yang tersembunyi (covert conflict) (Nasikun 1985).

Furnivall sebagaimana dikutip Nasikun (1985, 35-44) mensinyalir bahwa konflik pada masyarakat majemuk Indonesia menemukan sifatnya yang sangat tajam, karena di samping berbeda secara horisontal, kelompok-kelompok itu juga berbeda secara vertikal, menunjukkan adanya polarisasi. Artinya bahwa disamping terdiferensiasi secara kelompok etnik agama dan ras juga ada ketimpangan dalam penguasaan dan pemilikan sarana produksi dan kekayaan. Ada ras, etnik, atau penganut agama tertentu yang akses dan kontrolnya pada sumbersumber daya ekonomi lebih besar, sementara kelompok yang lainnya sangat kurang. Kemudian juga, akses dan kontrol pada sektor politik yang bisa dijadikan instrumen untuk pemilikan dan penguasaan sumbersumber daya ekonomi, juga tidak menunjukkan adanya kesamaan bagi semua kelompok.

Kemajuan zaman yang diikuti globalisasi di segala bidang (ideology, politik, ekonomi, sosial, budaya serta teknologi informasi) menyebabkan semakin mempercepat benturan antara kelompok yang bermula pada persoalan ekonomi kemudian merambat pada persoalan kesukuan, bahkan agama. Samuel Hantington berpendapat dalam bukunya The Clash of civilization bahwa sumber utama konflik di dunia baru ini bukanlah ideologi atau ekonomi, budayalah yang akan menjadi 
faktor pemecah belah umat manusia dan sumber konflik yang dominan. Negara-bangsa masih menjadi aktor dominan dalam percaturan dunia, namun konflik utama dari politik global akan terjadi antara negara dan kelompok dari peradaban yang berbeda. Huntington memberi definisi bahwa peradaban adalah sebuah entitas terluas dari budaya, yang teridentifikasi melalui unsur-unsur obyektif umum, seperti bahasa, sejarah, agama, kebiasaan, institusi, maupun melalui identifikasi diri yang subyektif (Huntington, 1996: 42).

Dampak positif kemajemukan masyarakat Indonesia meliputi akulturasi budaya dan persatuan dan kesatuan Indonesia. Dari sisi akulturasi budaya kemajemukan suku, budaya, dan agama justru menyebabkan integrasi bangsa Indonesia berjalan secara harmonis. Kemajemukan bangsa Indonesia berdampak pada bertahannya negara ini dari gempuran bangsa asing selama lebih dari satu abad atau setelah didirikannya organisasi Boedi Oetomo pada tahun 1908, Sumpah pemuda tahun 1928 sampai dengan kemerdekaan Republik Indonesia.

Dampak negatif kemajemukan bangsa Indonesai jika dilihat dari suku, budaya, serta agama primodialisme, stereotipe etnik menjadi potensi konflik yang besar jika tidak dikelola dengan baik adalah sikap primordial kebudayaan daerah, agama dan kebiasaan di masa lalu tetap bertahan sampai kini. Sikap primordial yang berlebihan yang kemudian lazim disebut etnosentris saat ini sering menimbulkan konflik. Hal ini dikarenakan setiap anggota masyarakat mayoritas akan mengukur keadaan atau situasi berdasarkan nilai dan norma kelompoknya. Sikap ini menghambat tejadinya integrasi sosial atau integrasi bangsa. Primordialisme harus diimbangi tenggang rasa dan toleransi.

Sikap etnosentris dalam masyarakat majemuk sering diikuti oleh stereotip etnik yaitu pandangan umum suatu kelompok etnis yang menganggap kelompoknya lebih baik daripada etnis lain (Horton \& Hunt: 1984:65). Beberapa contoh bentuk disintegratif akibat primodialisme, stereotip etnik sebagai akibat etnosentrisme antara lain konflik Dayak dan Madura di Kalimantan (Republika February 2001), Konflik Jawa dan Aceh tahun 1975-2005 (Kompasiana 2014), konflik 
Papua, serta konflik Lampung yang melibatkan suku Bali dan Suku Lampung (Kompas Oktober 2012) dan lain sebagainya. Konflik-konflik merupakan bentuk kurang terbinanya multikultural di Indonesia.

Pada era Orde Baru di bawah kepemimpinan Presiden Soeharto, konflik-konflik antara etnik dapat diatasi oleh kekuatan militer yang selalu melakukan tindakan represif terhadap benih-benih perpecahan yang mengarah pada disientegrasi bangsa. Namun setelah dibukanya pintu demokrasi pada era kepemimpinan Presiden Habibie tindakan represif oleh militer tidak lagi sesuai untuk mengatasi konflik antar etnis. Gelombang demokrasi semakin terbuka yang berdampak pada tuntutan masyarakat atas penghormatan terhadap hak-hak asasi manusia (HAM) serta eksistensi kelompok masyarakat mengandung bahaya perpecahan suatu negara. Hal ini telah diramalkan oleh Samuel P. Huntington dalam the Clash of Civilization sebagaimana dikutip Mahfud (2006:viii) disebabkan oleh kebebasan berdemokrasi, yang mengarah pada tuntutan persamaan hak berpolitik, social, budaya, ekonomi, kesukuan, bahkan agama.

\section{Pendidikan Agama Berwawasan Multikultural: Sebuah Langkah Strategis Menciptakan Toleransi Dan Perekat Bangsa}

Pendidikan agama di sekolah sebagai salah satu mata pelajaran pada lembaga pendidikan formal sekolah memiliki peran strategis dalam usaha menanamkan pendidikan multikultural pada peserta didik. Namun menjadi sebuah pertanyaan besar bagi kita apakah prinsipprinsip pendidikan serta fungsi pendidikan sebagaimana tercantum dalam UU Nomor 20 tahun 2003 tentang Sistem Pendidikan Nasional telah terimplementasi pada tataran praktis di lembaga-lembaga pendidikan formal di Indonesia.

Pendidikan agama di sekolah sebagaimana dijelaskan PP Nomor 32 tahun 2013 tentang Standar Pendidikan menyatakan bahwa Pendidikan Agama dimaksudkan untuk membentuk peserta didik menjadi manusia yang beriman dan bertakwa kepada Tuhan Yang Maha 
Esa serta berakhlak mulia termasuk budi pekerti. Permenag RI Nomor 16 Tahun 2010 tentang Pengelolaan Pendidikan Pada Sekolah menyebutkan bahwa pendidikan agama adalah pendidikan yang memberikan pengetahuan dan membentuk sikap-sikap kepribadian dan keterampilan peserta didik dalam mengamalkan ajaran agamanya, yang dilaksanakan sekurang-kurangnya melalui mata pelajaran pada semua jalur, jenjang dan jenis pendidikan. Hal ini sebenarnya telah menunjukan bahwa pemerintah telah berusaha membentuk peserta didik menjadi multikulturalis.

Pada tataran realitas, cita-cita yang diusung pada UU Nomor 20 Tahun 2003, PP Nomor 32 tahun 2013 masih jauh dari harapan. Kita merasakan bahwa pendidikan agama di sekolah-sekolah kita pada umumnya belum menghidupkan pendidikan multikultural yang baik, bahkan cenderung berlawanan seperti saling menafikan, mengkafirkan, menjelekkan antara seagama maupun antar agama. Akibatnya, konflik sosial sering kali diperkeras oleh adanya legitimasi keagamaan yang diajarkan dalam pendidikan agama di sekolahsekolah daerah yang rawan konflik. Ini membuat konflik mempunyai akar dalam keyakinan keagamaan yang fundamental sehingga konflik sosial kekerasan semakin sulit diatasi, karena dipahami sebagai bagian dari panggilan agamanya.

Padahal dalam ajaran agama apapun mengajarkan untuk saling toleransi, saling menghormati, dan anti kekerasan antar umat beragama diajarkan pada masing-masing agama.

Dalam ajaran Islam anjuran untuk bertoleransi ada dalam beberapa dalil seperti dalam Al Quran Surat Annisa ayat 14 yang artinya "Tidak ada kebaikan pada kebanyakan bisikan-bisikan mereka, kecuali menyurub (manusia) memberi sedekah, berbuat makruf (baik), atau melakukan islab (perdamaian) di antara manusia".

Sedangkan dalam ajaran Kristen anjurann untuk saling menghormati ada dalam ajaran inkarnasi. Dalam ajaran inkarnasi Allah menyapa dan membangun hubungan komuniter dengan manusia melalui Yesus (inkarnasi). Supaya wahyu itu berarti/bermakna bagi 
manusia, maka Allah menggunakan bahasa manusia, dan manusia menjawabnya dengan bahasa dan kebudayaannya sendiri.

Dalam Agama Hindu prinsip toleransi dan saling menghormati terdapat dalam ajaran Tattwam Asi, Karmaphala dan Abimsa. Tattwam Asi merupakan ajaran sosial tanpa batas, segala makhluk adalah sama sehingga menolong orang lain berarti menolong diri sendiri dan menyakiti orang lain berarti juga menyakiti diri sendiri. Karma Phala merupakan suatu hukum sebab akibat (kausalitas) apapun yang dilakukan sengaja maupun tidak sengaja akan menimbulkan dampak/ akibat yang harus dipertanggung jawabkan. Dan Abimsa yang berarti tanpa kekerasan, secara etimologis ahimsa berarti tidak membunuh tidak menyakiti hati makluk hidup lainnya.

Dalam ajaran Buddha terdapat ungkapan sarva dharma samabhdva. Ungkapan tersebut secara harfiah diartikan bahwa semua dharma/ kebenaran (agama) adalah sama dan saling selaras satu sama lainnya.

Paparan tentang multikultural dan pendidikan agama di atas menjadi sebuah catatan penting bahwa multikulturalisme adalah sebuah fakta, fakta semakin bercampur baurnya penduduk dunia yang mampu memberikan tekanan pada sistem pemerintahan, pendidikan, dan ekonomi yang telah mapan untuk berubah (Baidhawy, 2005:1). Multikulturalisme mencakup suatu pemahaman, penghargaan serta penilaian atas budaya seseorang, serta suatu penghormatan dan keingintahuan tentang budaya etnis orang lain (Lawrence Blum, dikutip Lubis, 2006:174). Multikultural sebuah ideologi yang mengakui dan mengagungkan perbedaan dalam kesederajatan baik secara individual maupun secara kebudayaan (Suparlan, 2002)

Pendidikan multikultural adalah merupakan suatu gerakan pembaharuan dan proses untuk menciptakan lingkungan pendidikan yang setara untuk seluruh siswa (Arifin, 2012:74). Zakiyudin Baidhawy dalam buku Pendidikan Agama berwawasan Multikultural (2005) menyebutkan bahwa pendidikan multikultural adalah suatu cara mengajarkan keragamaan (teaching diversity). Pendidikan multikultural menghendaki rasionalisasi etis, intelektual, sosial dan pragmatis secara 
inter-relatif yaitu mengajarkan ideal-ideal inklusivisme, pluralism, dan saling menghargai semua orang dan kebudayaan merupakan imperative bumanistic yang menjadi prasyarat bagi kehidupan etis dan partisipasi sipil secara penuh dalam demokrasi multikultural dan dunia manusia yang beragam. (2005:8).

Pendidikan multikultural diartikan sebagai proses pendidikan yang memberikan peluang sama pada seluruh anak bangsa tanpa membedakan perlakuan karena perbedaan etnik, budaya, dan agama dalam upaya memperkuat persatuan dan kesatuan, identitas nasional dan citra bangsa di mata dunia internasional. Pendidikan multikultural mempersiapkan peserta didik untuk aktif sebagai warga negara dalam masyarakat yang secara etnik, kultural, dan agama beragam. Pendidikan multikultural diperuntukkan bagi semua peserta didik tanpa memandang latar belakang suku, agama, dan budayanya. Konsep pendidikan multikultural sangat relevan diterapkan di Indonesia yang plural dengan beragam suku, agama, dan budaya, dalam rangka memupuk jiwa toleransi pada peserta didik dalam menyikapi realita kemajemukan yang ada di setiap pergaulannya.

Christy Winchester (2004:17) dalam disertasinya yang mereview teori James Banks menyebutkan bahwa pendidikan multikultural telah terbukti menjadi sebuah media yang tepat untuk membicarakan halhal yang sulit terkait dengan kesukuan, jenis kelamin, kelas sosial, agama, seksualitas, dan lainnya. Banyak peserta didik setelah mengkiuti pendidikan multikultural mampu berpikir tentang keragaman dan komponen terkait dalam cara-cara baru setelah mengalami kursus dan telah memiliki kesempatan untuk secara terbuka mendiskusikan masalah yang sedang dihadapi.

Berangkat dari kondisi obyektif bangsa Indonesia yang memiliki tingkat kemajemukan yang cukup tinggi, maka untuk bisa hidup dalam sebuah masyarakat yang multikultur paling tidak ada empat sikap yang harus dimiliki masyarakat Indonesia. Empat sikap ini meliputi inkulisivisme, humanisme/egalitarianism, toleransi, dan demokarsi (Effendi, 2004:2). 
Pendidikan agama berwawasan multikultural mengusung pendekatan dialogis untuk menanamkan kesadaran hidup bersama dalam keragaman dan perbedaan. Pendidikan multikultural selama ini salah dipahami hanya sebatas memasukan isu-isu etnik atau rasialpadahal lebih dari itu pendidikan multikultural juga mengedepankan isu-isu lainnya seperti relasi gender, keragaman sosial, ekonomi dan perbedaan agama serta lain sebagainya (Baidhowy:75-76).

Baidhowy merumuskan pedoman relative untuk memaknai pendidikan agama berwawasan multikultural terkait 7 hal sebagai berikut (Baidhowy 78-85). Pertama, belajar hidup dalam perbedaan. Pengembangan sikap toleran, empati, dan simpati merupakan prasayarat esensial bagi keberhasilan koeksistensi dan proeksistensi dalam keragaman agama. Toleransi adalah kesiapan dan kemampuan batin untuk kerasan bersama orang lain yang berbeda secara hakiki meskipun terdapat konflik dan pemahaman tentang apa yang baik dan jalan hidup layak. Menjadi toleran adalah membolehkan orang lain menjadi diri mereka sendiri, menghargai orang lain, asal usul dan latar belakang mereka selalu bermakna menolak membicarakan pada orang lain apa yang harus dilakukan dan bukan keinginan untuk mempengaruhi mereka agar mengikuti ide kita. Pendidikan agama berwawsan multikultural dirancang untuk menanamkan sikap toleran dari tahap yang minimalis dari dekoratif hingga solid.

Kedua, membangun saling percaya. Rasa saling percaya adalah salah satu modal sosial terpenting dalam membangun masyarakat kultural. Modal sosial ini dapat digunakan untuk menganalisis kondisi-kondisi yang membuat upaya ke arah penguatan masyarakat madani. Disamping saling percaya sumber-sumber non material di dalam masyarakat bisa berupa status, niat baik, kemerdekaan warga negara, toleransi, dan penghormatan terhadap atauran hukum norma-norma, jaringanjaringan yang dapat meningkatkan efisiensi sosial dengan memudahkan tindakan-tindakan yang terkoordinasi. Modal sosial ini merupakan fondasi bagi terbangunnya sikap rasional. Tidak mudah curiga, bebas dari prasangka, dan stereotip baik yang dikonstruksi secara sosio 
cultural maupun secara politik. Agama diyakini sebagai faktor penting dalam pembentukan budaya etnisitas atas nama agama dan dapat menyebabkan berkembangnya prasangka tertentu antar kelompok agama yang mungkin ditanamkan dan diwariskan secara sadar maupun tidak sadar dari satu generasi ke generasi berikutnya. Pendidikan multikultural menggaris bawahi perlunya pencerahan penanaman mutual trust antar agama, antar kultur dan antar etnik (Baidhowy 7885).

Ketiga, memelihara saling pengertian. Saling memahami sama artinya saling bersimpati pada sesuatu namun memahami bukan berarti menyetujui. Saling memahami adalah kesadaran bahwa nilai-nilai mereka dan kita dapat berbeda dan mungkin saling melengkapi serta member kontribusi terhadap relasi yang dinamis dan hidup sehingga lawan akan menjadi mitra yang saling melengkapi. Pendidikan agama mempunyai tanggung jawab membangun landasan etis kesaling sepahaman antara etnisitas-etnisitas agama dan budaya yang plural sebagai sikap dan kepedulian sesame (Baidhowy 78-85).

Keempat, menjunjung sikap saling menghargai. Pendidikan agama berwawasan multikultural bersuaha menumbuh kembangakan kesadaran bahwa kedamaian mengandaikan saling menghargai antar penganut agama-agama, yang dengannya kita dapat dan siap untuk mendengarkan suara dan prespektif agama lain yang berbeda.saling menghargai akan membawa pada sikap saling berbagi di antara semua individu dan kelompok.

Kelima, terbuka dalam berfikir. Pendidikan seyogyanya mampu menumbuhkan kematangan dalam berfikir dan bertindak tentang apa yang seharusnya diberikan kepada siswa. Pendidikan agama berwawasan multikultural mengkondisikan siswa untuk saling berjumpa dengan pluralitas pandangan dan perbedaan radikal yang menantang identitas lama dan segalanya mulai tampak dalam sinar baru. Hasilnya diharapkan kemauan siswa untuk mampu memulai pendalaman tentang makna diri, identitas, dunia kehidupa, agama dan kebudayaan diri sendiri serta orang lain (Baidhowy 78-85). 
Keenam, apresiasi dan interdepensi. Pendidikan agama dalam dimensi ini hendakanya perlu membagi kepedulian tentang apresiasi dan interdepensi umat manusia dari berbagai tradisi agama-agama. Hal ini dikarenakan banyak sisi kehidupan manusia yang tidak dapat di atasi secara material oleh limpahan harta, uang, tahta dan kekayaan. Perlu tanggungjawab untuk mencipta bersama sebuah masyarakat yang membantu semuanya.

Ketujuh, resolusi konflik dan rekonsiliasi nirkekerasan. Konflik antara agama adalah kenyataan yang tidak terbantahkan dari masa lalu dan masa kini. Pendidikan agama harus hadir untuk menyuntikan spirit dan kekuatan spiritual sebagai sarana integrasi dan kohesi sosial. Pendidikan agama perlu memfungsikan agama sebagai satu cara dalam resolusi konflik. Namun demikian rosolusi konflik belum cukup tanpa rekonsiliasi yakni upaya perdamaian melalui sarana pengampunan atau memaafkan. Pendidikan agama perlu meyakinkan bahwa agama-agama sesungguhnya mengajarkan bahwa balasan untuk kejahatan adalah kejahatan yang serupa dengannya (Baidhowy 78-85).

Pendidikan agama berwawasan multikultural mempersiapkan siswa untuk aktif sebagai warga negara dalam masyarakat yang secara etnik, kultural, dan agama beragam. Pendidikan multikultural ini diperuntukan untuk semua siswa tanpa memandang latar belakang agama, etnisitas, dan kebudayaan.

James A. Banks (2002:14) menyebutkan dimensi pendidikan multikultural yang terdiri dari lima dimensi. Dimensi-dimensi ini dalam pendidikan multikultural diperkirakan dapat membantu guru agama dalam mengimplementasikan beberapa program yang mampu merespon terhadap perbedaan pelajar (siswa), yaitu:

Pertama, dimensi integrasi isi/materi (content integration). Dimensi ini digunakan oleh guru agama untuk memberikan pembelajaran dengan mengintegrasikan nilai-nilai budaya dan agama yang ada disekitarnya. Secara khusus, para guru agama dapat menggabungkan kandungan materi pembelajaran ke dalam kurikulum dengan beberapa cara pandang 
yang beragam. Di samping itu guru agama dituntut memiliki kemampuan menyusun kurikulum yang mengarah pada materi-materi multikulturalisme (Banks , 2002:14).

Kedua, dimensi konstruksi pengetahuan (knowledge construction) yaitu suatu dimensi yang menggambarkan keaktifan guru agama dalam membantu peserta didik untuk memahami, menyelidiki, dan menentukan bagaimana asumsi budaya serta agama implisit, serta mengajarkan bagaimana bersikap pada masyarakat yang multikultural. Dimensi berhubungan dengan pemahaman para pelajar terhadap perubahan pengetahuan yang ada pada diri mereka sendiri.

Ketiga, dimensi pengurangan prasangka (prejudice reduction). Dimensi pengurangan prasangka pada pendidikan multikultural adalah kegiatan yang dilakukan oleh guru agama dalam usaha membantu siswa untuk mengembangkan sikap rasial yang positif dan demokratis. Hal ini juga membantu siswa untuk memahami bagaimana etnis identitas dipengaruhi oleh konteks sekolah dan sikap dan keyakinan kelompok sosial yang dominan (Banks , 2002:14).

Keempat, dimensi pendidikan yang sama atau kesetaraan dalam pendidikan (equitable pedagogy). Dimensi ini lebih tepatnya adalah memodifikasi startegi mengajar guru dalam mengimplementasikan pendidikan multikultural di dalam kelas. Dimensi ini juga menyangkut pendidikan yang dirancang untuk membentuk lingkungan sekolah, menjadi banyak jenis kelompok, termasuk kelompok etnik, wanita, dan para pelajar dengan kebutuhan khusus yang akan memberikan pengalaman pendidikan persamaan hak dan persamaan memperoleh kesempatan belajar (Banks , 2002:14).

Kelima dimensi pemberdayaan budaya sekolah dan struktur sosial (empowering school culture and social structure). Dimensi ini penting dalam memperdayakan budaya siswa yang dibawa ke sekolah yang berasal dari kelompok yang berbeda. Di samping itu, dapat digunakan untuk menyusun struktur sosial (sekolah) yang memanfaatkan potensi budaya siswa yang beraneka ragam sebagai karakteristik struktur sekolah setempat, misalnya berkaitan dengan praktik kelompok, iklim sosial, 
latihan-latihan, partisipasi ekstra kurikuler dan penghargaan staff dalam merespon berbagai perbedaan yang ada di sekolah (Banks, 2002:14).

\section{Tujuan Penulisan Bunga Rampai}

Bunga rampai ini disusun berdasarkan hasil penelitian tentang pendidikan agama berwawasan multikultural yang dilakukan oleh peneliti-peneliti Balai Litbang Agama Semarang pada tahun 2015. Secara umum tujuan penelitian tersebut adalah mendeksripsikan implementasi pendidikan agama yang berbasis multikultural pada SMA di Provinsi Bali, yang meliputi deskripsi pemahaman guru agama dalam menyusun kurikulum pendidikan agama berbasis multikultural, deskripsi budaya sekolah dalam mendukung implementasi pendidikan agama berbasis multikultural deskripsi tentang persepsi siswa sebagai evaluasi terhadap hasil pembelajaran pendidikan agama berbasis multikultural serta diperolehnya deskripsi faktor pendukung dan penghambat dalam implementasi pendidikan agama berbasis multikultural pada SMA di Provinsi Bali.

Lokus Penelitian Provinsi Bali menjadi sangat penting karena daerah ini merupakan daerah yang masih kental mengusung ada dan budaya Bali ditengah banyaknya perpindahan penduduk dari luar Bali menuju dan menetap di provinsi ini.

\section{Metode Penelitian}

Penelitian ini menggunakan pendekatan kualitatif, yakni penelitian yang bermaksud untuk memahami fenomena tentang apa yang dialami oleh subjek penelitian misalnya perilaku, persepsi, motivasi, tindakan dan lain-lain, secara holistik dan dengan cara deskripsi dalam bentuk kata-kata dan bahasa, pada suatu kontek khusus yang alamiah dan dengan memanfaatkan berbagai metode alamiah (J.Moleong, 2008:6). Dalam penelitian ini peneliti sebagai instrumen kunci, untuk melihat kurikulum pendidikan agama, proses pembelajaran, budaya sekolah, 
presepsi siswa, dan faktor yang mempengaruhi pendidikan agama berbasis multikultural di SMA.

Subyek penelitian dipilih berdasarkan pada tinggi rendahnya tingkat multikulturalitas wilayah Bali. Kkabupaten Klungkung, dan Tabanan merupakan bagian wilayah provinsi bali dengan tingkat pluralitas dan multikulturalitas rendah. Sedangkan Kota Denpasar, Kabupaten Badung dan Buleleng merupakan wilayah Bali yang memiliki tingkat pluralitas tinggi Sasaran penelitian pada bunga rampai pendidikan agama berbasis multikultural ini adalah Sekolah Menengah Atas Negeri (SMAN) dan SMA Swasta yang berada wilayah tersebut.

Teknik pengumpulan data dalam penelitian ini menggunakan empat macam teknik, yaitu wawancara, observasi, dokumen, dan kuesioner. Teknik-teknik tersebut digunakan untuk memperoleh data yang telah ditentukan dalam instrumen pengumpulan data.

Uji keabsahan data dalam bunga rampai penelitian ini adalah trianggulasi data yang diartikan sebagai teknik pengumpulan data yang bersifat menggabungkan dari berbagai teknik pengumpulan data dan sumber data yang telah ada. Dalam hal ini peneliti melakukan pengumpulan data sekaligus menguji kredibilitas data yaitu mengecek kredibilitas data dengan berbagai teknik pengumpulan data dan berbagai sumber data.

Analisis data dilakukan mulai dari persiapan, studi awal, pengumpulan data di lapangan, dan setelah selesai pengumpulan data di lapangan. Analisis data pada tahap persiapan dilakukan dengan membuat rumusan masalah yang tepat dengan berpijak pada fenomena multikultural dan pendidikan multikultural yang ada di SMA, khususnya di Provinsi Bali.

Analisis data hasil studi awal dilakukan untuk memperoleh potret pendidikan agama berbasis multikultural yang sudah ada dan diterapkan di beberapa SMA di Provinsi Bali. Analisis dilakukan terhadap datadata tentang pelaksanaan pembelajaran pendidikan agama berbasis multikultural, mulai dari kegiatan perencanaan, proses pembelajaran, sampai pada evaluasi hasil pembelajaran. Hasil analisis data digunakan 
sebagai acuan pelaksanaan pengumpulan data di lapangan sekaligus sebagai bahan perumusan model pendidikan agama berbasis multikultural yang ideal melalui kegiatan Focus Group Discussion (FGD).

\section{Kerangka Pikir}

Multikultural dan pluralitas bangsa Indonesia merupakan sebuah keniscayaan yang harus diterima oleh negara ini. Kemajemukan dan keragaman budaya, etnik, agama memiliki potensi berupa integrasi dan disintegrasi jika tidak dikelola dengan baik.

Pendidikan agama berwawasan multikultural di sekolah merupakan salah satu cara untuk mengelola kemajemukan bangsa kita sehingga tidak menimbulkan konflik dan berakibat pada disentegritas. Komponen-kompenen yang diberdayakan dalam mengelola pendidikan agama berwawasan multikultural meliputi; kurikulum pendidikan agama (content integration), pendidik, tenaga kependidikan, lingkungan sekolah, dan kepemimpinan kepala sekolah dengan memasukan dimensi belajar dari perbedaan, membangun saling percaya, memelihara saling pengertian, menjunjung sikap saling menghargai, terbuka dalam berfikir, apresiasi dan interdependensi, resolusi konflik dan rekonsiliasi nirkekerasan. Jika digambar alur pikir penelitian ini digambarkan sebagai berikut. 


\section{Bagan 1}

\section{Kerangka Pikir Penelitian}

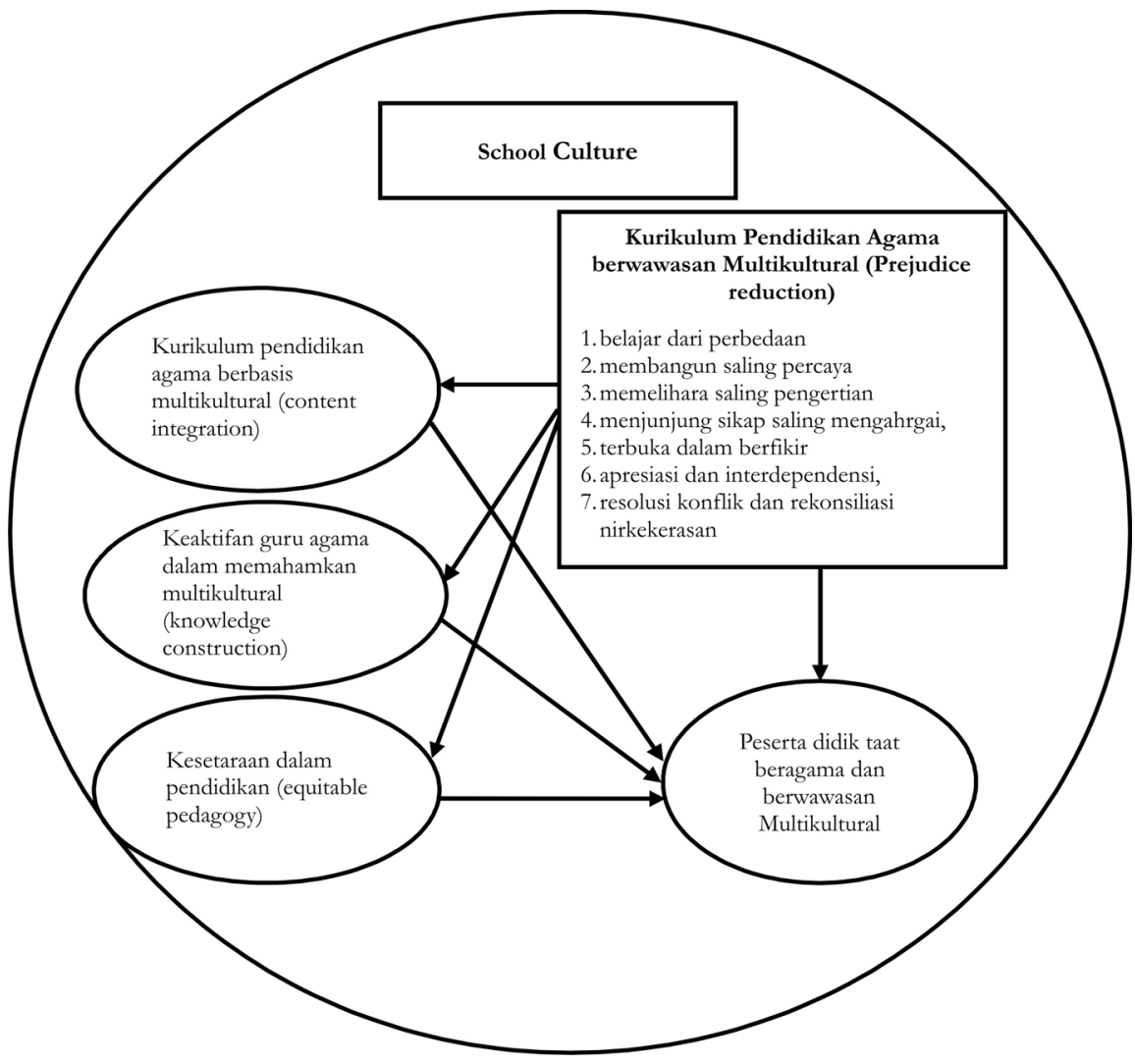

\section{DAFTAR PUSTAKA}

Arifin Al, Ahmad Hidayatullah, implementasi pendidikan multikultural Dalam praksis pendidikan di Indonesia, Jurnal Pembangunan Pendidikan: Fondasi dan Aplikasi, Volume 1, Nomor 1, Juni, 2012

Azra, Azyumardi, 2007. "Identitas dan Krisis Budaya, Membangun Multikulturalisme Indonesia",http://www.kongresbud. budpar.go. id/58\%20ayyumardi\%20azra.htm

Baidhawy, Zakiyudin, 2005. Pendidikan agama berwawasan multikultural, Erlangga, Jakarta 
Banks, James A. 2002. An introduction to Multikultural Education, BostonLondon: Allyn and Bacon Press

Coser, Louis. 1956. The Functions of Social Conflict. New York: Free Press.

Effendi, Lutfi, 2004. Empat Sikap tuntutan Masyarakat Multikultural, Suara Muhammadiyah No 4/Th Ke 89, Februari

Geriya, I Wayan, 2004, Visi dan Strategi Kebudayaan Bali ke Depan dan Penjabaran ke Dalam Misi dan Tujuan PKB. (dalam MUDRA: Jurnal Seni Budaya Vol.14 No. 1 Januari 2004). ISI Denpasar.

Hidayat, Komarudin, 2000. Konflik Antar Agama,Kompas 18 Januari Horton, Paul B. \& Hunt, Chester. L. (1984). Sosiologi, Jilid II edisi keenam. Jakarta: Erlangga http://id.wikipedia.org/wiki/Demografi_Indonesia http://www.bakosurtanal.go.id/berita-surta/show/indonesiamemiliki-13-466-pulau-yang-terdaftar-dan-berkoordinat

http:www.duniaesai.com/antro/antro3.html Suparlan, Parsudi, "Menuju Masyarakat Indonesia yang Multikultural", Simposium Internasional Bali ke-3, Jurnal Antropologi Indonesia, Denpasar Bali, 16-21 Juli 2002, 1987]

Lubis, Akhyar Yusuf, 2006. Deskontruksi Epistemologi Modern. Jakarta: Pustaka Indonesia Satu

Mahfud, Choirul. 2008. Pendidikan Multikultura, Yogyakarta : Pustaka Pelajar

Moleong, Lexy, J. 2008. Metode Penelitian Kuantitatif. Bandung. Remaja Rosdakarya.

Nasikun. (1984). Sistem Sosial Indonesia. Jakarta: Rajawali Press

Sunarto, Kumanto, Russel Hiang-Khng Heng, dan Achmad Fedyani Saifudin (eds.), 2004, Multicultural Education in Indonesia and Southeast Asia Stepping in to the Unfamiliar, Depok: Jurnal Antropologi Indnesia 
Winchester, Cristy, 2004, James Banks' Levels Of Multikultural Integration And A Discourse Analysis Of Selected Virtual Graduate Level Diversity Courses, University of South Carolina

Wasino, 2012. Model Pembelajaran Ips Di Sekolah Menengah Pertama Dan Sekolah Menengah Atas Berwawasan Multikultural Sebagai Upaya Pencegahan Konflik-Konflik Sosial Di Jawa Tengah, Hibah Penelitian Tim PascasarjanaHPTP (HIBAH PASCA), Universitas Negeri Semarang 


\section{PENDIDIKAN MULTIKULTURAL DI PULAU DEWATA}

(Sebuah Bunga Rampai tentang Fendidikan Multikultural Pada SMA di Provinsi Bali)

Penulis: A.M. Wibowo, dkk.

Editor: Mulyani Mudis Taruna

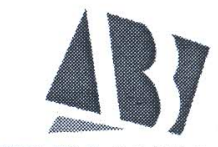

ARTI BUMIINTARAN 


\section{DAFTAR ISI}

SAMBUTAN KEPALA BALAI LITBANG AGAMA SEMARANG — iii PENGANTAR EDITOR. — viii PENGANTAR AHLI: Prof. Dr. Wasino, M.Hum. - xiii DAFTAR ISI. — xix

PROLOG: PENGEMBANGAN POTENSI TOLERANSI DAN PERSATUAN BANGSA MELALUI PENDIDIKAN AGAMA BERWAWASAN MULTIKULTURAL

A.M Wibowo. - 1

IMPLEMENTASI PENDIDIKAN AGAMA BERBASIS MULTIKULTURAL PADA SMA DI PROVINSI BALI (Studi pada SMA Surya Wisata di Kabupaten Tabanan Propinsi Bali)

Ali Khudrin. - 23

PENDIDIKAN AGAMA BERBASIS MULTIKULTURAL PADA SMA DI PROVINSI BALI (Studi pada SMAN 1 Tabanan Provinsi Bali)

Wahab. - 53

MENGGALI MULTIKULTURALISME DI SEKOLAH (Studi terhadap SMA Katolik Soverdi Badung)

Siti Muawanah. - 85

PENDIDIKAN AGAMA DALAM BINGKAI BUDAYA MULTIKULTURALIS DI SEKOLAH (Studi Pendidikan Multikultural di SMAN 1 Kuta)

Umi Muzayanah. - 115 
PENDIDIKAN AGAMA BERWAWASAN MULTIKULTURAL PADA SMA SWASTA DI KABUPATEN KLUNGKUNG (Studi pada SMA Pariwisata Saraswati Kabupaten Klungkung) A.M. Wibowo. - 149

IMPLEMENTASI PENDIDIKAN AGAMA BERBASIS MULTIKULTURAL DI SMA NEGERI I SEMARAPURA, KLUNGKUNG, BALI.

Mukbtaruddin. - 185

IMPLEMENTASI PENDIDIKAN AGAMA BERBASIS MULTIKULTURAL DI SMA LAB. UNDIKSHA SINGARAJA PROVINSI BALI

Abmad Muntakbib. - 217

IMPLEMENTASI PENDIDIKAN AGAMA BERBASIS MULTIKULTURAL DI PROVINSI BALI (Studi pada SMA Negeri 1 Singaraja Kabupaten Buleleng)

Mulyani Mudis Taruna 245

IMPLEMENTASI PENDIDIKAN AGAMA BERWAWASAN MULTIKULTURAL DI SMA TAMANRAMA DENPASAR BALI

Yusriati. - 279

EPILOG: PENDIDIKAN AGAMA BERWAWASAN MULTIKULTURAL

Yustiani S.. -315

BIODATA PENULIS. - 331 